\title{
Overcoming High Anxiety by the Means of a Person-Centered Intensive Program Psychotherapy
}

\author{
Lusine Aramayis Grigoryan \\ Psychological centre "Zhesture”, Yerevan, Armenia
}

\begin{abstract}
The article presents one case of overcoming high anxiety through Person-Centered Intensive Program Psychotherapy, which is carried out by a program designed special for the problem of that person.

The overcoming of the problem is presented in the article with a description of each visit, and the deadline assigned to cope with the problem.

The article presents diagnostic method of high anxiety of the client.

For overcoming this problem, gestalt techniques were used to ensure the entirety and completeness of the clients.

Secondary interests, childhood traumas, anxiety transmitted from ancestries, the role of the anxious parent or others which are at the basis of the problem are presented. As in the case of each problem the overcoming high anxiety is possible by the client's realization of the abovementioned causes of the problem.

The article also presents high anxiety statistics for clients of the Psychological Center "Zhesture" for the past 3 years.
\end{abstract}

Key words: high anxiety, trauma, secondary interest, gestalt

\section{Introduction}

Anxiety is one of the most important emotional-psychological states that accompany humanity and speaks to the stress resistance of the individual and the sensitivity of the contradiction to the situation.

Pearls noted: "When you have anxieties about what you have done, it is not anxieties about what you have done, but anxieties about what the punishment will be in the future." 1

Since the initial stage of human ontogenetic development, he has discomfort when he encounters whatever he does not know, he is afraid of, or cannot influence. But if in one case the anxiety is short-term, a mental state, from which he comes out on his own, then on the other hand it becomes such a state that decreases the quality of life, depriving him of the opportunity to have a joy, dream, rest, harmony and self-

${ }^{1}$ [Dzhanni Franchesetti 'Panicheskie ataki', Moskva 2015g., 263 p]: 


\section{Social science, Humanities \& Education}

15 - 17 December, 2020

Berlin,Germany

confidence. That is why it is important to understand why a person has a high anxiety, which allows him to make choices about what to do and how to behave. [Karen Horni. «Nevroticheskaja lichnost' nashego vremeni» 1993, 165 p]:

\section{Case in Germany: Psychological birth after anxiety}

High anxiety is accompanied by the following symptoms or some of them that reach their peak within 10 minutes:

1. Tachycardia

2. Increased sweating

3. Trembling

4. Feeling of suffocation

5. Asphyxiation

6. Pain or compression in the chest

7. Nausea, gastrointestinal tract disorder

8. Dizziness

9. Feeling unreal

10. Fear of losing self-control or getting crazy

11. Fear of death

12. Feeling overwhelmed

13. Heartburn

[Karen Horni. «Nevroticheskaja lichnost' nashego vremeni»1993, 165 p]

Often the anxiety is accompanied by various fears of death, mistake, criticism, loss, etc., which is diagnosed with the Sheehan Anxiety Rating Scale (ShARS)). A variety of factors contribute to the formation of high anxiety, such as personality traits (psychological, physiological traits, life experience), and family inheritance in the form of anxiety, negative perceptions of own self.

- The legacy of a high anxiety family, when there are traumas in the family or in generations that have not been overcome (missing relatives, human losses...), which, however, are not often talked about in the presence of children, do not explain what death is and the child sees the anxiety of adults, but receives no explanation. The child begins to make assumptions, and through the defense mechanisms the fantasy joins, he begins to imagine.

- Negative perceptions of the own self, when parents' overwhelming demands for the child cause anxiety, and if the child does not implement those demands, he receives expressions such as "you can't", "you won't succeed", "you are looser", and so on. An adult still has the same anxiety as a child.

It is not possible to discuss the anxiety without addressing the issue of death or to study the death without addressing the anxiety, nor to investigate the cause of the anxiety or the psychology of death without analyzing the impact of maternal anxiety. Every mother has a major impact on her daughter's life, often becoming a source of anxiety for her, and boys are also victims in the case of the influence of the mothers' 


\section{Social science, Humanities \& Education}

anxiety, but unlike girls, they do not become mothers. For girls, such influence creates the fear of becoming a mother; there are women who reject not only their gender but also their acceptance as a wife and mother. Almost every woman dreams of pregnancy and at the same time is afraid of it. The woman enjoys her pregnancy, but the anxiety makes her terminate her pregnancy. The anxiety of a pregnant woman is transmitted to the baby who is forming in her. Difficulties in pregnancy that may have a negative effect on the fetus in this case result from rejection of motherhood. Even if the anxiety has been manageable during pregnancy and the childbirth has passed without complications, the crisis may occur after childbirth. At this stage, a conflict arises between the woman, in one case the desire to be a caring and loving mother, in the other case not imagining herself in that role, which causes her anxiety and is transmitted to the child. [Dzhozef S. Rejngol'd «Mat', trevoga i smert'. Kompleks tragicheskoj smerti», 2004, 153 p]

Freud distinguished two versions of the anxiety:

- Anxiety is caused by the suppression of sexual pleasure that is expressed physiologicaly. If the sexual desire is not satisfied, then this energy causes tension in the body, which is expressed by an anxiety.

- Anxiety arises not only from fear of sexual but also from other aggressive aspirations that can pose an external threat.

Talking of the childhood of an anxious man, Freud distinguishes the environment from which the child receives warmth. A child can cope with many traumas, such as stopping breastfeeding, beatings, sexual problems, if he feels desirable and loved. A child feels when love is false, he cannot be deceived by the show. The main reason why a child does not get enough warmth from his parents is because of the traumas of his parents' childhood. On the other hand, parental overcare for the child in the near future causes a feeling of insecurity when the child is no longer an adult but cannot move confidently without his parents; there is an anxiety of uncertainty about the future. In this case, the technique of "parental hands" is applied within gestalt therapy, as a result of which the child grows up, refuses the help of the parental hands, and standing firmly on his feet goes ahead. The more a child conceals his disagreement in the family obeying to his parents' decisions to receive warmth from them, the more he projects his anxieties to the outside world, gaining the conviction that the whole world is dangerous and fearful. [Karen Horni. «Nevroticheskaja lichnost' nashego vremeni» 1993, 165 p]:

The number of clients with the complaint of anxiety to the Psychological Center "Zhesture" has increased drynamically. By the way, from the call center, the anxious client is distinguished by his haste, the exaggeration of emotions (the typical 


\section{Social science, Humanities \& Education}

expressions are: I am very bad, I want to meet right now, I am afraid of dying, of getting crazy). In the call center within the framework of the person-centered intensive program psychotherapy, a preliminary conversation is held with him, the person calms down and leaves the high anxiety very quickly. We received a call that a specialist in the call center was able to "save" him. The dynamic increase in the statistics below can be interpreted as an increase in human demands in the new technology era, a change in values, and a willingness to apply for psychological support .
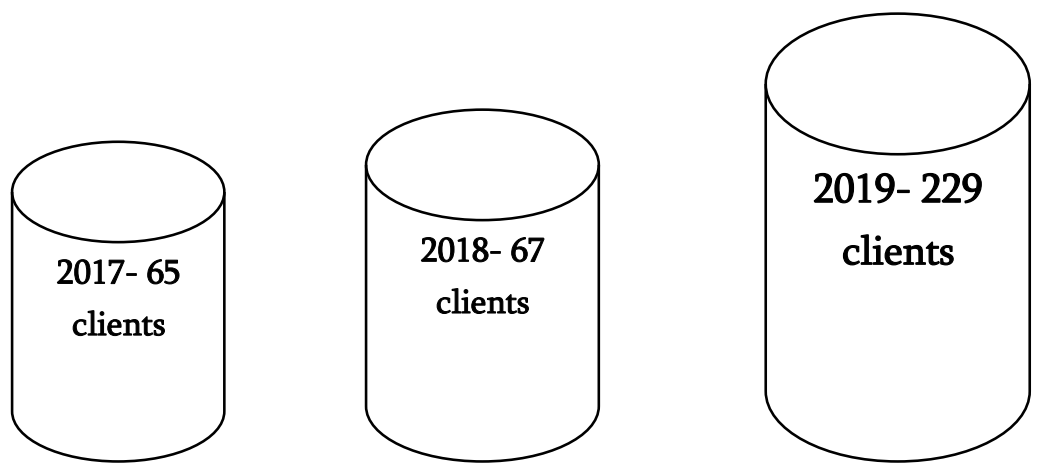

There are presented projective self-portrait of clients with high anxiety where there are strokes, lines drawn in the same direction, some of which are strongly accentuated. In two of the pictures, the anxieties are directed to the past, whereby fears are directed to the future, and in the third, the client does not feel her body at all, she also has sexual problems and anxiety related to them. The first and third pictures have a lack of colors. In the first picture, the client demonstrates self-confidence, trying to hide her anxiety. The second and third pictures show indifference to own self [Venger A. L. Psihologicheskie risunochnye testy]: 
$4^{\text {th }}$ International Conference on Social science, Humanities \& Education

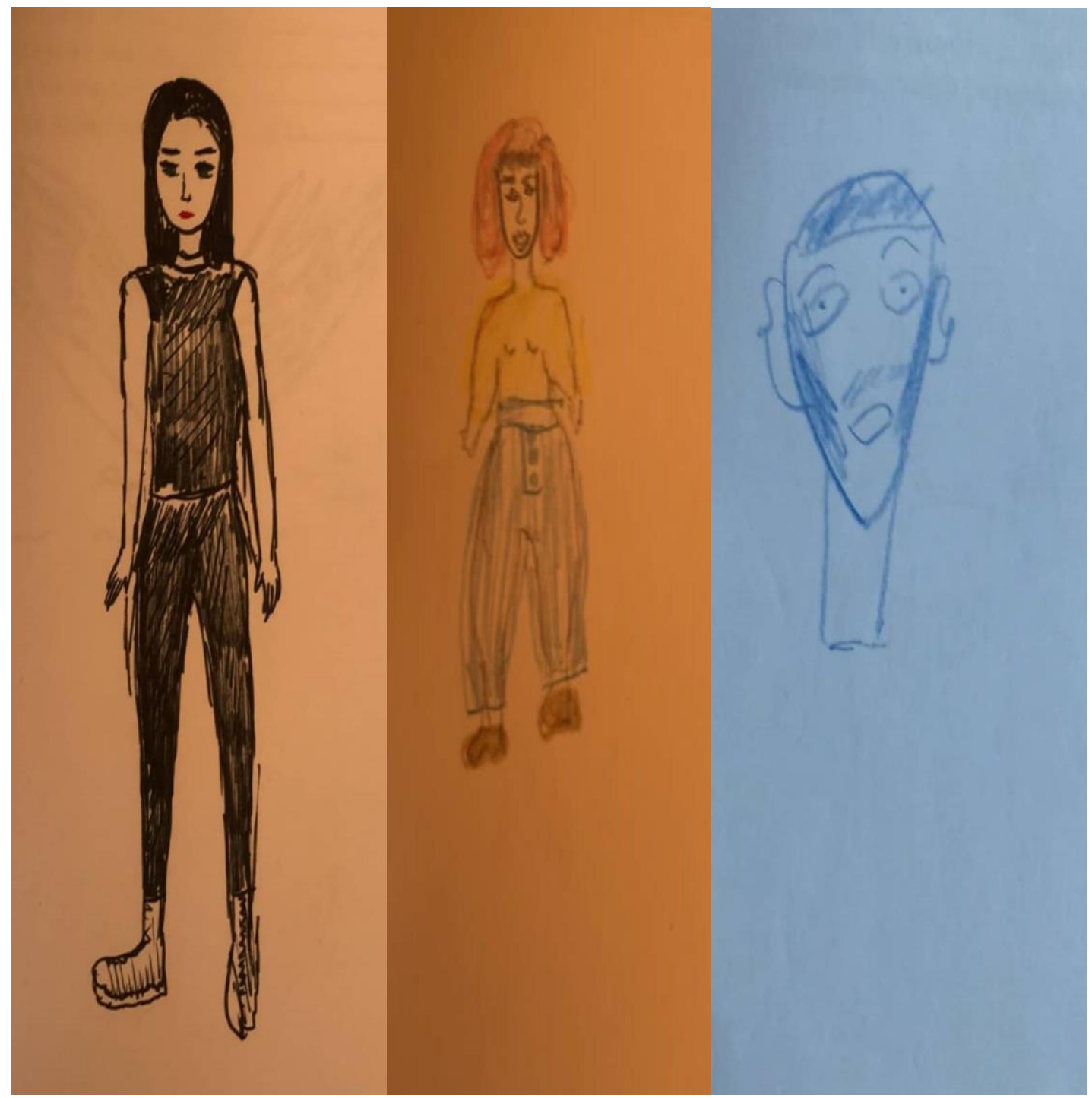

"My family" projective methodology, where the client's anxiety and family connection is evident. Lack of emotional connection in the family, presence of a younger brother, a jealousy about which the client is not mentioning, she becomes isolated and selfcontained. There are the anxious parents and anxious client in the picture. [Venger A. L. Psihologicheskie risunochnye testy]: 
$4^{\text {th }}$ International Conference on Social science, Humanities \& Education

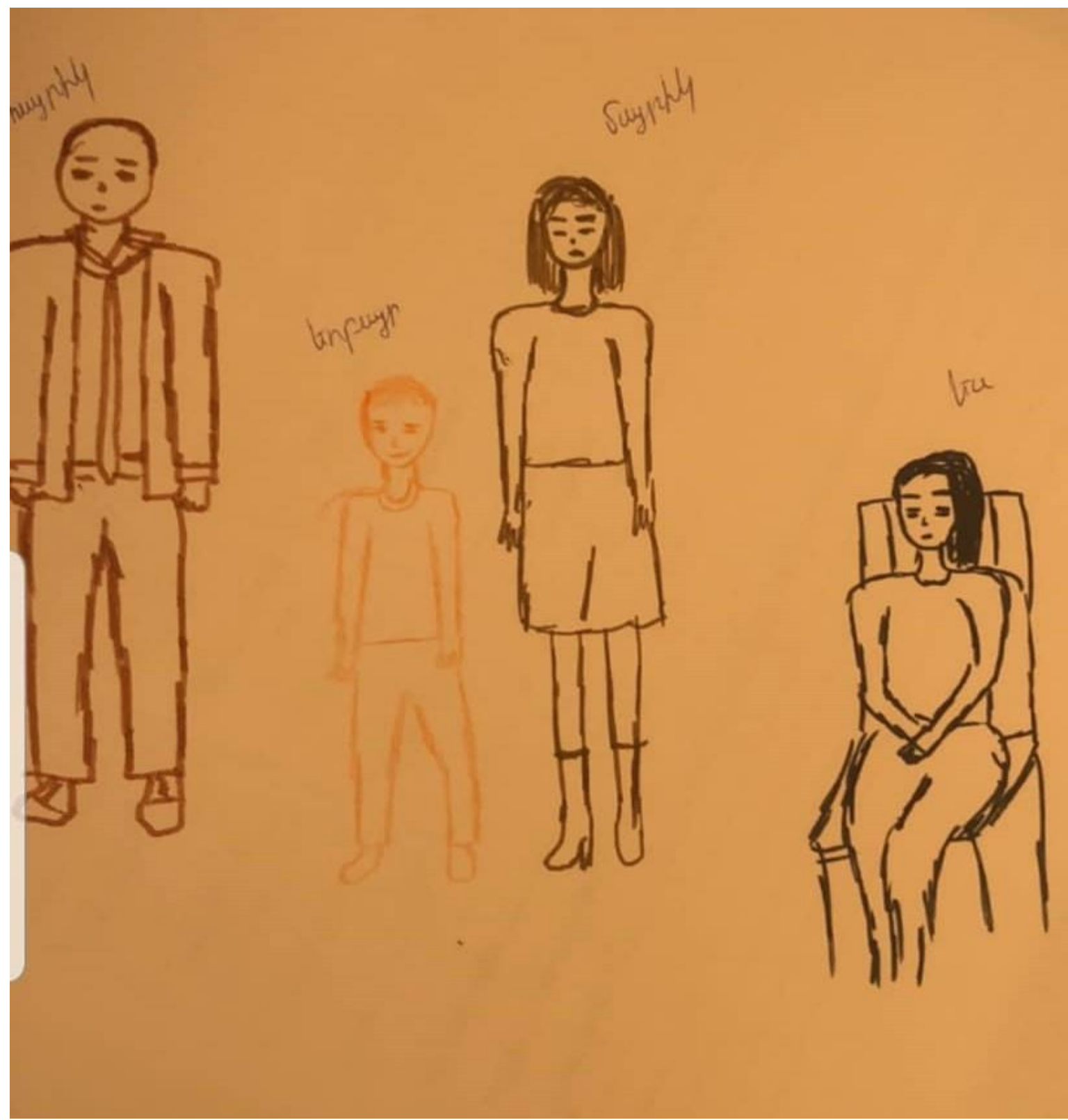

Below is a case of overcoming high anxiety:

Client-46 years old

Sex: female

The client lives in Germany, the work has been done online, there have also been 2 Meetings in Armenia. 
$4^{\text {th }}$ International Conference on

\section{Social science, Humanities \& Education}

15 - 17 December, 2020

Berlin,Germany

The client has been experiencing high levels of anxiety for about two years, arising from her return from Germany to Armenia. The woman had applied to the Psychological Center "Zhesture" long after coming to the psychiatric hospital and taking psychotropic drugs.

Complaint: A feeling of suffocation or a feeling of overwhelmed in the throat, a feeling of compression in the chest, a fear of death or a feeling that something terrible may happen, a fear of getting crazy or loss of self-control, a fear of height.

Sheehan Anxiety Rating Scale (ShARS)) was implemented with the client. Result maximum 140 points. This is considered a clinically high rate.

There were 24 meetings with the client within the framework of psychotherapy.

Meeting 1- Under the care of maternal grandmother till the age of 6 whom she called a mother (she saw her mother once a month or later). Grandma's most beloved grandchild, to whom everything is permissible. Moving the paternal house /while attending to school/ where she did not adapt. Now the client has overcare for her children, especially for her daughter, for becoming such a mother for her whom she would like to have herself. The symbiotic relationship with the mother has been broken, and now there is no emotional connection to the mother.

Meeting 2- Grandmother's anxious image. Childhood memory: Grandma used to say "don't come up to the height, the devil will enter you, you will fall". Fear to the client, whether I throw me down. In the framework of Gestalt therapy we have been working with art therapy overcoming the fear of height (in this case the grandmother's position at the base of the fear of height).

Meeting 3,4- Artsakh, the years of war, the same anxiety situation that she feels now, her father is at the front. Memory: We were going into the basement during the shootings. Fear of height: it is safer in the basement. Surviving and overcoming the emotions of the child at that years through the use of gestalt techniques.

Meeting 5- Early marriage at the age of 16 to a man who is 13 years older from her. Difficulties in a new family, my husband didn't protect me /insult/. Work on a gestalt technique, an "empty chair," in which she expressed her insults and accusations through a dialogue with her husband. During the technique, she also realized her responsibilities and expectations from her husband.

Meeting 6- Dad's death, feeling guilty, her father was against my marriage, and he didn't forgive her. Overcoming Father's Loss and Feeling Guilty by means of 
$4^{\text {th }}$ International Conference on

\section{Social science, Humanities \& Education}

15 - 17 December, 2020

Berlin,Germany

gestalt technique, "Letter to Father," which relieved her of the feeling guilty for her father.

Meeting 7,8- Work with a woman on her husband's insults by gestalt technique, "everything I've long kept silent about." After applying the technique, after expressing the insult towards her husband, overcoming the feeling of suffocation and the feeling of overwhelmed

Meeting 9,10- Husband's betrayal, insult from him, grandparents' favorite grandchild had the same expectations from her husband that didn't work out. Lowering expectations of the client, focusing on her husband's positive sides. Meeting 11,12- A new life, new positive changes after moving to Germany, but a psychological problem with the client after coming to Armenia and returning back. Memories of the past in Armenia: war / years of anxiety for a young child /, father's death / loss, self-blame /, husband's betrayal / insult /

Fear of height in Germany - fear of losing what she has acquired.

Meeting 13, 14, 15- Secondary benefit of high anxiety of the client:

- The need of constant attention / Grandma's beloved granddaughter /, expectations from her husband. A Client's words: When I'm not feeling well, my husband is more attentive.

- Lack of intimate relationships with her husband. The wife's words: he used to betray me, he's grown now, and I'm still young, but I don't want to have a relationship with him, punishing him for his abusive past. Rejecting intimate relationship with the husband-I do not feel good.

Meeting 16, 17, 18- Work with client's and grandmother's characters, I do not continue my grandmother's scenario; I forgive my mother for missing those 6 years. Grandmother's stories that caused anxiety to the child. I can now distinguish my anxiety from my mother's and my grandmother's anxiety.

Meeting 19, 20- A visit to Armenia, but unlike the previous one, there is no anxiety in Armenia, memories do not torture, this time she came to enjoy Armenia. Unlike the previous visit, the client has overcome the past and being in Armenia only creates positive memories of the past.

Meeting 21-24- After returning to Germany, four more meetings where the client found a job (before she hadn't been leaving home) began to follow her as a woman, not to reject her husband. The client no longer has short-term, situational 
$4^{\text {th }}$ International Conference on

\section{Social science, Humanities \& Education}

15 - 17 December, 2020

Berlin,Germany

anxieties which she can easily get out of. Fears, psychosomatic problems are overcome.

\section{Conclusion}

Thus, in this case, overcoming high anxiety through Person-Centered Intensive Program Psychotherapy planned for that person and, most importantly, meeting intensity gave an opportunity to realize the causes of high anxiety, to overcome the anxiety of a child within the adult becoming such an adult for her whom the child within herself will trust, understand the causes of high fear (grandmother's position, trauma gained after the war, it is safer in the basement, as well as fear of losing what she has obtained). Maintain own personal boundaries by separating own anxiety from another's. The combination of Gestalt therapy techniques with transactional analysis, cognitive techniques enabled the woman to have a new quality of life with new approach, to achieve worldview changes, to approach optimally the anticipated difficulties causing anxiety.

\section{References}

1. Dzhanni Franchesetti (2015). "Panicheskie ataki", Moskva., 263 p

2. I.G. Malkina (2004). Pyh Tehniki geshtal'ta i kognitivnoj terapii»: Jeksmo; Moskva;, $154 \mathrm{p}$

3. Karen Horni (1993) Nevroticheskaja lichnost' nashego vremeni, $165 \mathrm{p}$

4. Venger A. L. Psihologicheskie risunochnye testy: Illjustrirovannoe rukovodstvo

5. Dzhozef S. Rejngol'd (2004) Mat', trevoga i smert'. Kompleks tragicheskoj smerti, $153 \mathrm{p}$ 